\title{
Desertification-Climate Change Interactions - Mexico's Battle Against Desertification
}

\author{
Carlos Arturo Aguirre-Salado1, Eduardo Javier Treviño-Garza², \\ Oscar Alberto Aguirre-Calderón², Javier Jiménez-Pérez², \\ Marco Aurelio González-Tagle ${ }^{2}$ and José René Valdez-Lazalde ${ }^{3}$ \\ 1 Universidad Autónoma de San Luis Potosí \\ 2Universidad Autónoma de Nuevo León \\ ${ }^{3}$ Colegio de Postgraduados \\ Mexico
}

\section{Introduction}

Until a few centuries, Earth enjoyed a fragile balance in the ecosystem. With the development of mankind this balance has started to lose. More than one is starting to believe that the imbalance is modifying Earth's climate. This is evident in the increasingly frequent news on natural disasters. Both forest and soil degradation have contributed to anger the weather, which has responded directly or indirectly through destruction processes, fostering biological organisms to congregate on continuing the chaos (Allen et al., 2010).

It is a common idea that droughts cause desertification. While the lack of rain is a contributing factor, the root causes are related to the overexploitation of the environment by humans. Droughts are common in arid and semiarid lands, but lands with good management can recover when rains return (Runnström, 2000, Rasmussen et al., 2001). However, the persistent abuse of the land plus drought increases land degradation. Larger population and agricultural pressure on marginal lands accelerates desertification (Viglizzo \& Frank, 2006). In some areas of the world such as Africa and Asia, nomads migrate to less arid regions and disrupt the local ecosystem by increasing the rate of soil erosion. While trying to escape from desert, the wilderness pursues them with their practices in land use (UNCCD, 2004; Henson, 2008, Barua et al., 2010). Thus, poor people become both the cause and the victims of land degradation (Günter et al., 2009).

For Mexico, the regulation of the General Law for Sustainable Forest Development defines desertification as the loss of productive capacity of land caused by nature or man in any ecosystem (DOF, 2005). Although this definition assumes the concept completely, it is worth contrasting it with the one used by the United Nations Convention to Combat Desertification (UNCCD) which reads: "Land degradation in arid, semiarid and subhumid lands, is the loss of biological or economic productivity and complexity of agriculture (irrigation and temporal), pastures, woods and forests that results from a process or combination of processes including those promoted by the man such as: a) water or wind erosion, b) deterioration of physical, chemical and biological soil properties and) the permanent loss of vegetation." This definition is used worldwide to describe desertification and its impacts (Grainger et al., 2000). 
Causes of desertification vary worldwide. These can be divided into two groups (Geist \& Lambin, 2004), 1) those that predispose desertification called underlying causes and 2) those that physically start a desertification process, called proximate causes. Among underlying causes are climate, economics, institutions, national policies and remote influences of population growth. While proximate causes include the expansion of agriculture, overgrazing and infrastructure development. Climate variability represented by meteorological phenomena acts concomitantly and synergistic with other drivers. magnitude of storms or duration of droughts can also be drivers to start desertification process. Economic factors such as market conditions can induce abandonment of arid lands that were used someday for agriculture leading land degradation and thus desertification. Social factors like in- or out-migration determine the potential amount of people available to work in field. Both situations can precede degradation, while immigration could exert higher pressure on land, out-migration would start abandonment of agriculture land. Policy and institutional related factors can also foster degradation. These drivers are associated to formal development policies such as market liberalization, money injection to farming sector as subsidies, incentives or credits. Others have stated that property rights of land tenure have not worked well, weakening conservation of ecosystems in arid lands and predisposing land to excessive grazing, best illustrated by the Tragedy of Commons.

Earth system works following a series of rules or consequences called feedbacks or interactions. When one climatic variable changes, it alters another in a way that influences the initial variable that fostered the change. There are positive and negative feedbacks. A positive feedback stimulates an increase on the initial variable response. For example, global warming reduces snow cover in winter, increases both surface albedo and absorption of solar energy by ground, thus average temperature becomes higher. Or when, land use change reduces retention and availability of soil moisture, hindering the establishment of flora and leading to more soil degradation until a desert area appears. By other hand, negative feedbacks include an amelioration of effects in this circular process. For example, global warming could induce more water vapour in the air, thus more cloud formation which can reflect more sunlight to space, thereby reducing the amount of heating of the surface and with that reversing the initial warming process. Depending on the systems involved, these types of chain reaction can lead to a variety of responses to any ecosystem perturbation (Borroughs, 2007).

Further describing these relationships, at local and regional scales, involves understanding how human activities alter the Earth's surface and influence its atmospheric behaviour. In turn, it will be interesting to evaluate the opposite, i.e. how desertification affect weather conditions in soils, ecosystems, water balance and land use in arid regions (Sivakumar et al., 2007; Bied-Charreton, 2008). These interactions generate a vicious circle which if we do not stop it with specific actions of conservation and restoring, the productive capacity of a particular field could be completely lost. In this sense, the objective of this Chapter is to address these interactions and pinpoint the actions that both the Mexican government and civil society are tackling to fight every day against desertification, mitigating these twodirectional effects between Earth ecosystem and climate.

\section{Influences of desertification on climate}

The awareness that climate influences both the development and distribution of plants and animals, comes from prehistoric times. While recognizing that ecosystem changes have an 
influential effect on climate change is a recent concern. Vegetation degradation includes a temporal or permanent reduction in the density, structure and species composition. These changes may accelerate climate impacts and exacerbate climate variability (Grainger et al., 2000; Ustin et al., 2009).

\subsection{Land use and land cover change}

Land degradation caused by land use changes is one of the main themes of the environmental research agenda. This process normally starts with the replacement of forest vegetation for subsistence farming, while the productive potential is retained; otherwise, the reduction of nutrients shore to drop. As a consequence, grazing is the next activity (Viglizzo \& Frank, 2006). The introduction of cattle reduces the likelihood for ecosystem restoration. Forest seedlings are part of the diet of animals; besides soil compaction, created by the grazing, eliminates any possibility of water retention and hence growth and development of new forestation (Arnalds et al., 2004). Another possible cause of land degradation is deforestation propelled by forest fires. Although fire may be used as a tool for forest management and even some pine species require high temperatures to open and download off the seeds (Juárez \& Rodríguez, 2003), forest fires are uncontrolled events that eliminate vegetation by burning and emit into the atmosphere large amounts of greenhouse gases.

Terrestrial ecosystems contain three or four times more carbon than atmospheric $\mathrm{CO}_{2}$, and more than $1 / 8$ of atmospheric $\mathrm{CO}_{2}$ is exchanged within a year by ecosystems through the process of photosynthesis and respiration (Burroughs, 2007). These natural flows of $\mathrm{CO}_{2}$ are approximately 10 times larger than the flux of anthropogenic additions which are blamed for global warming. In Mexico, it is common the occurrence of fires of various magnitudes during the dry season from December to August. The average annual occurrence of forest fires for the period 2000-2005 was 7880, affecting an average annual area of 208,000 ha. The most common causes of forest fires were agricultural activities (42\%), campfires of tourists $(10 \%)$, smoking $(9 \%)$, forestry $(4 \%)$, burning of garbage $(3 \%)$, poaching $(2 \%)$, near roads $(2 \%)$ and unspecified causes $(27 \%)$. This shows the impact of emissions of greenhouse gases by land use change on global climate (SEMARNAT \& INE, 2006).

Another point-of-view related to deforestation and climate change is that tree cutting in urban areas affects so much more global warming than the same activity occurring outside-city. This is explained by the increasing need of air-conditioning in urban areas, which leads to a higher microclimate temperature, thereby raising the use of more and more energy resources such as electricity, especially in warm and dry climates (Rappaport \& Hammond, 2007).

\subsection{Albedo and energy exchange}

The amount of solar radiation that can be reflected or scattered into space is defined as the surface albedo. Surface albedo is closely related to Earth's energy flux. Desert sand reflects much more solar energy than any wooded ecosystem, so the consequences of desertification are an alteration of the radiation balance of the areas affected by this degradation process. The amount of solar energy available at the surface for heating the atmosphere depends on the surface albedo, which varies by location, season and land use. The worldwide average 
albedo is around 0.3 , but ranges from 0.9 to less than 0.05 . Bare-soil albedo ranges from 0.1 to 0.6 , while albedo of forested areas varies from 0.08 to 0.15 . Large changes in albedo occur in regions suffering desertification and deforestation. Depending on soil albedo, the reduction in vegetation cover can lead to an increase in the albedo. An increase in surface albedo could decrease surface temperature (Burroughs, 2007; Rafferty, 2011).

\subsection{Evapotranspiration and relative moisture}

The removal of vegetation decreases the reduction of water vapor flowing into the atmosphere by evapotranspiration, this process will additionally impact on reducing the relative humidity and on the possibility of cloud formation (Andréassian, 2004; Geist \& Lambin, 2004; Burroughs et al., 2007). Other climate impact of evapotranspiration is the regulation of temperature. Thus lower evapotranspiration rates could induce a warmer effect on environmental temperature, and vice versa (Davoudi et al., 2009).

\subsection{Surface roughness, wind speed and dust storms}

The sun generates energy at about 345 watts $/ \mathrm{m}^{2}$. Approximately $30 \%$ of this energy is reflected back into space and is never used in the atmosphere-land system. Of the remainder, slightly less than $1 \%\left(3.1\right.$ watts $\left./ \mathrm{m}^{2}\right)$ accelerates the air and creates the wind. Without tree cover, the continents would offer less friction to the wind, and wind speeds in un-vegetated landscapes would be about twice as fast compared to the places covered with forest vegetation, increasing the potential for wind erosion. Therefore, as desertification creates vegetation of lower size will therefore lower values of surface roughness and as a result, increased wind speed over previous patterns observed in landscapes with greater vegetation height (Rafferty, 2011). The opposite also occurs, a greater wind speed can contribute to an increase on soil erosion ( $\mathrm{Lu} \&$ Shao, 2001), thus consequently more desertification.

By other way, dune formation is a process mainly observed in the major sand deserts of the world. Desertification, understood as the progress of desert areas, is well pictured in these regions. Great dunes rapidly change overtime and disappear any productive land such as agriculture or small towns (Kusky, 2009). Another interaction relating wind and soil after land degradation is the generation of dust storms. Particles flying in the atmosphere reflect solar energy over a broadband, including the infrared and thus have a cooling effect (Hardy, 2003). In addition, dust storms cause several impacts. For example, dust storms in Asia have a great impact on the air quality of cities of China, Korea and Japan. The same is for African dust storms which effects reach European countries; in America, dust storms also disrupt social an economic activities. Several efforts of land management to minimize dust storms have done worldwide by planting trees and shrubs that endure long dry periods, and in some cases establishment of induced grasslands can be used to feed cattle and for improving quality of living of people in arid lands (Shao \& Dong, 2006).

\subsection{Overgrazing}

Rangelands in semi-arid zones are especially vulnerable to desertification. Nowadays around $73 \%$ of this type of land has been degraded (Oldfield, 2005). Grass provides a 
complete cover and perennial protection of the ground, which result in minimal soil erosion due to the high probability of seed germination, and to a strong root network that gives more cohesion to soil particles. But, when cattle exert overgrazing, the phantom of desertification comes in. Overgrazing is widely regarded as one of the major causes of desertification in arid lands due to depletion of pasture and scrub and accelerated soil loss. When soil is trampled and compacted by livestock, it loses its ability to establish vegetation and moisture conservation, resulting in increased evaporation and runoff. Additionally, an overgrazing process can be detected as a plant cover decrease, the replacement of original species and the undeniable soil erosion footprint. Thus, overgrazing can exacerbate the impact of drought by modifying the microclimate of the soil, altering the water retention, exposing bare soil to erosion (Manzano \& Návar, 2000; Santini et al., 2010; Amiraslani \& Dragovich, 2011).

Viglizzo \& Frank (2006) described a complete picture of interaction between ecosystem and climate caused by the mismanagement in the Argentine Pampas. Deforestation, overgrazing, intensive agriculture and improper harvesting technology with the interaction of extreme drought conditions between 1930 and 1940 caused severe sandstorms, mortality in livestock, crop failure, failure of bankers and migration. Subsequently, as weather improved they returned to agricultural activity. But during the period 1970-2002 recurrent episodes of flooding in the basin River Quinto happened, probably, by an excessive intensification of agricultural activities in the area.

\subsection{Land degradation and agriculture}

Soil degradation assessment in Mexico suggests that almost 1'200,000 ha are affected by some degree of salinization. The states with the highest incidence are Tamaulipas, Sonora, Baja California, Chihuahua, Coahuila, Colima (CONAZA, 1994; SEMARNAT \& COLPOS, 2003). The high presence of salts degrades soil fertility and promotes abandonment of the land. Additionally, surface albedo increases after progressive salinization. Fujimaki et al. (2003) found that increasing the concentration of salt in the soil at a rate of $1 \mathrm{mg} / \mathrm{cm}^{2}$ results in an increase in the albedo of 0.0002 . By increasing the albedo, the temperature decreases because there is less absorption of solar energy.

Another feedback or interaction relating agriculture, degradation and climate, is the potential retention of carbon by the soil. It is estimated that the ratio between carbon stocks in soil and standing biomass is about 20/1 respectively in semiarid lands, compared with a typical moist forest with a $1 / 1$ ratio (Grainger et al., 2000). When sustainable agriculture practices such as conservation tillage are used, carbon stocks in soil, root and aboveground biomass (284-306Mg/ha/year) can be comparable to those in forested lands. So, climate impact if soil carbon is released to atmosphere could be comparable to that caused by typical deforestation of aboveground forest carbon pools (Etchevers et al., 2009).

\section{Influences of climate on desertification}

Considering the climate variability reported in recent times, it inspires revisiting the potential effects of climate on land desertification following land degradation, but under a climate-change perspective. 


\subsection{Effects on pests and land cover change}

Allen et al. (2010) conducted an extensive global review of the experiences reported from studies of tree mortality related to climate, particularly drought and heat. In the case of North America, they reported approximately 20 million ha affected from Alaska to Mexico (Table 1). This mortality was led jointly by climatic and biotic factors: 1) multi-year drought, 2) high temperatures preceded by very cold winters, and 3) dramatic incidence of forest pests such as bark beetles of the genera Dendroctonus spp, Ips spp and Scolytus spp or defoliators of the genus Malacosoma sp.

\begin{tabular}{|l|l|c|l|}
\hline \multicolumn{1}{|c|}{ Place } & \multicolumn{1}{|c|}{ Host } & Area affected (ha) & \multicolumn{1}{c|}{ Reference } \\
\hline Alaska & Picea spp & $>1^{\prime} 000,000$ & Berg et al. (2006) \\
\hline British Columbia, Canada & Pinus contorta & $>10^{\prime} 000,000$ & Kurz et al. (2008) \\
\hline $\begin{array}{l}\text { Saskatchewan and Alberta, } \\
\text { Canada }\end{array}$ & $\begin{array}{l}\text { Populus } \\
\text { tremuloides }\end{array}$ & $1^{\prime} 000,000$ & Hogg et al. (2008) \\
\hline Southwest United States & Pinus edulis & $1^{\prime} 000,000$ & $\begin{array}{l}\text { Breshears } \\
\text { et al. (2005) }\end{array}$ \\
\hline Missouri and South Carolina & $\begin{array}{l}\text { Quercus } \\
\text { velutina } \\
\text { Q. coccinea } \\
\text { Pinus jeffreyi y } \\
\text { Abies concolor }\end{array}$ & Not reported & Savage et al. (1997) \\
\hline $\begin{array}{l}\text { California, U.S. and Baja } \\
\text { California, Mexico. }\end{array}$ & Clinton et al. (1993) \\
\hline
\end{tabular}

Table 1. Some cases of tree mortality in North America (Allen et al., 2010)

Low temperatures in winter had naturally controlled insect populations. When not enough cool years came, insects proliferated and then husked or defoliated millions of trees. This fact increased the vulnerability of forest to fires due to the amount of combustible material generated by tremendous mortality (Henson, 2008, Letcher, 2009). The devastation caused by tree mortality and poor restoration of these ecosystems could be the beginning of a long and painful process of desertification, even though such areas are not near major deserts of the world.

Several impacts of climate change on forestry are also expected. Although some researchers view positively the increase in global temperature, which could augment productivity in U.S. forests, they also accept that higher incidence of forest fires, pests and diseases may occur (Latta et al., 2010). Thus, forest spatial distribution and composition changes and their effects on biodiversity are the main forecasting. Changes in forest habitat distributions are also expected. Forest species will look for cooler areas to establish themselves, which probably will be at higher altitudes or latitudes. Interesting colonisations of broadleaved species in temperate ecosystems are expected because of warmer conditions to grow.

Other researchers have highlighted some others vulnerabilities to climate change relating water into vegetation. Conifers are more capable of endure drought than broadleaves because of their higher resistance to xylem cavitation processes (Maherali et al., 2004; Cochard, 2006). Thus, climate change could lead negative effects on world forestry because 
severe consequences on investing for intensive forest management and supply of forest products could be occur in a near future (Lal et al., 2011).

\subsection{Effects on soil degradation}

The possible negative effects of climate change on the soil could be that an increased temperature and low rainfall in arid zones would reduce the incorporation of organic matter up to $25 \%$ (Kemp et al., 2003). Organic matter acts as a bonding between soil particles and promotes soil unity and stability. When a soil lacks of organic matter can be more vulnerable to wind and water erosion. This can precede more dramatic situations. When increasing temperature, speed wind becomes higher and more aggressive causing sandstorms. These scenarios are common in the great deserts in the world which expand to higher latitudes, shifting regions that were once fertile (Goudie, 2008; Kusky, 2009).

Assessment of soil loss can be carried out by direct and indirect methods. Direct methods comprise in situ measurements that can be made by different ways. For example, Pando et al. (2002) used the method of nails and washers to determine the loss of soil in an arid basin located in Nuevo Leon, Mexico as an indicator of desertification. The values ranged from 15 ton/ha (0-8\% slope, with zero and low vegetation) and 151.7 ton/ha (> 30\% slope) for one year of measurement. Other researchers have made indirect estimates using databases and applying models to estimate water erosion by combining the rainfall erosivity, soil susceptibility to erosion, the degree and length of slope and vegetation cover integrated into an Universal Equation Soil Loss (Zhou et al., 2008, Beskow et al., 2009). Others have integrated to this information the predominant direction of winds and existing windbreaks using GIS to determine the risk of wind erosion (Podhrázscká \& Novotný, 2007; Santini et al., 2010).

Temperate zones do not escape from degradation. The increase of storms, combined with the deforestation caused by illegal logging in some regions of Mexico has led to the outbreak of large-scale landslides. For example, during an unusual event of extreme precipitation attributed to climate change because occurred outside the period of rain (15 hours of continuous precipitation in January 2010), the town of Angangueo, Michoacan, Mexico was almost fully covered by liquefied soil, detached from the mountains by the extreme humidity. Navarrete et al. (2011) found that illegal logging explained $61 \%$ of total degradation in that area. This area has global ecological importance because its temperate forests serve as habitat for the monarch butterfly (Danaus plexipus) when migrating from northern areas such as Canada.

Desertification is a multifactor process. When it was started from bad conditions, high variability of climate, social instability and overexploitation of natural resources all factors will work together following a downward spiral of overall degradation with no stop. But, the opposite is also possible. Increased biological productivity consciously managed can lead to effectively conserve ecosystem and to foster political and economic stability. It is easier to move from right to left due to worldwide conditions (Figure 1). But, there are experiences of people who though different, and started from a degraded environment and slummy economic circumstances, improving their future with great courage and a great vision. 


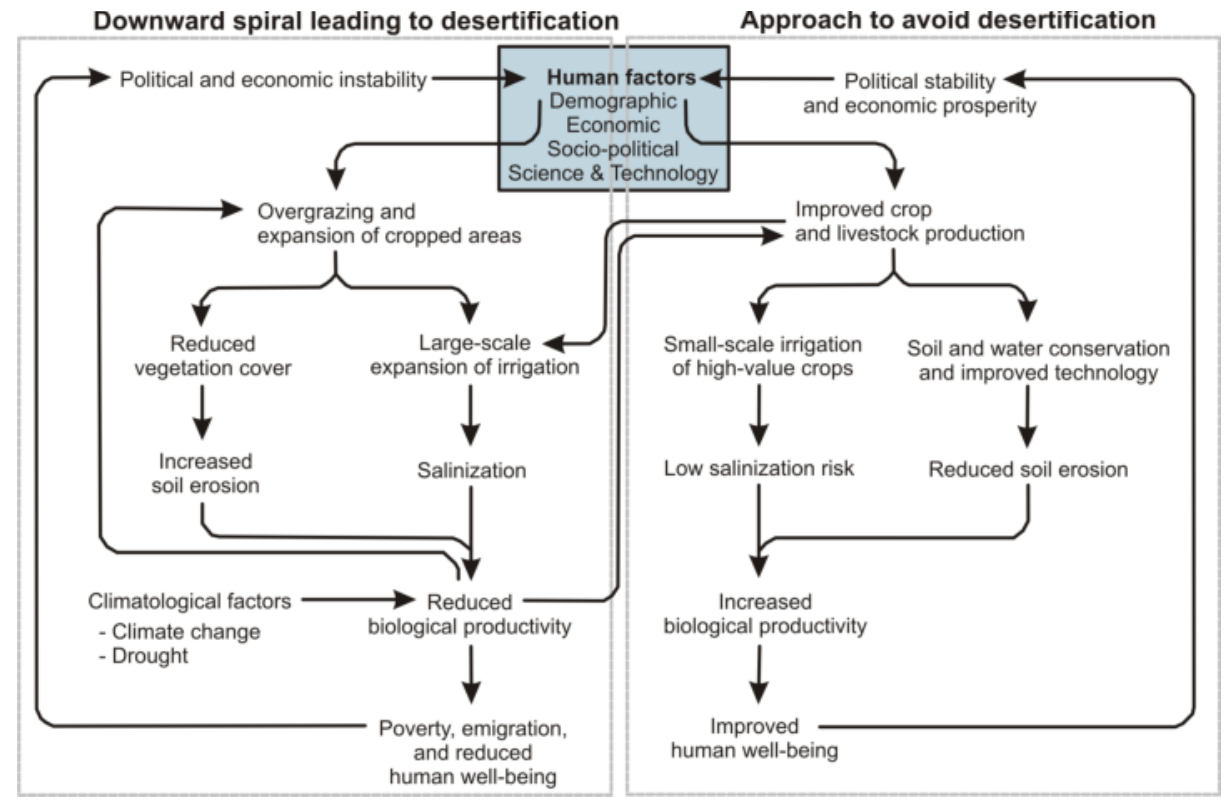

Fig. 1. Flowchart of desertification. (Adapted from Millennium Ecosystem Assessment, 2005)

\section{Actions against desertification in Mexico}

One of the main problems that have increased the country's vulnerability to climate change has been the rapid deforestation of the country. This can boost severe cases of desertification, an extreme situation of land degradation that is very difficult to reverse. In developing countries, like Mexico, deforestation is due to illegal logging and the expansion of the agriculture activities at the cost of land suitable for forestry, destroying fragile ecosystems as complex as both forests and woodlands. Payment for environmental services can be a good choice (SEMARNAT, 2009).

Currently the federal government of Mexico, through the Ministry of Environment and Natural Resources has created a council or committee called the National System for Combating Desertification and Degradation of Natural Resources (SINADES, as called in Spanish) whose primary objective is to coordinate efforts against desertification and degradation of natural resources by promoting programs that involve different levels of government and civil society.

For proper functioning of SINADES with relevance to the current scenario of Mexico, it was raised the need to formally update the Action Plan to Combat Desertification in Mexico made in 1994 by the Arid Zones National Commission (CONAZA, as called in Spanish). After wide participation of society, through a public consultation including 27 state workshops, 6 regional forums, one national workshop and an electronic query, it was made the document called National Strategy for Sustainable Land Management presented during the World Day to Combat Desertification and Drought (June 17, 2011) in Mexico. This 
document integrates eight key strategic lines: 1) to promote awareness throughout society and focus on Sustainable Land Management, 2) to promote the integrated planning of land use, 3) to strengthen institutional coordination and harmonization of policies, 4) to promote the generation and dissemination of information for Sustainable Land Management, 5) to promote co-responsible citizen participation, inclusion and gender and ethnic equity, 6) to strengthen research and transfer of good management practices, 7) to foster international cooperation, and 8) to design integrated financing strategies (SINADES, 2009).

The National Forestry Commission of Mexico (CONAFOR, as called in Spanish) through the ProArbol program provides incentives to forest owners who wish to perform actions for the protection, conservation, restoration and sustainable use of forest resources in Mexican ecosystems. CONAFOR has applied financial support for conservation and restoration in almost 494,000 ha from 2001-2007. Since 2005, CONAFOR has been the main partner of United Nations Convention to Combat Desertification in Mexico. One of the major projects implemented to combat desertification include the reforestation of degraded areas for soil conservation (Figure 2).

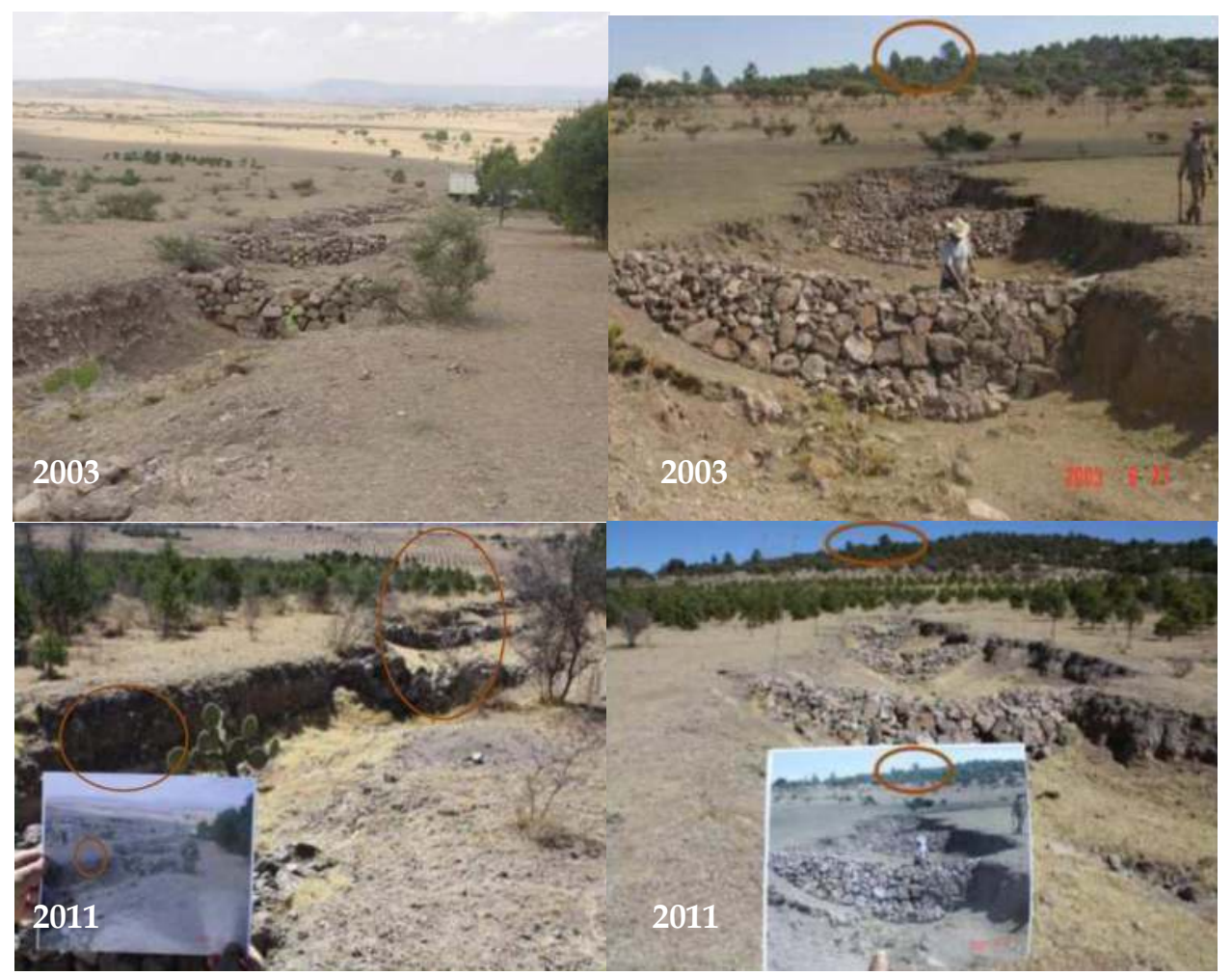

Fig. 2. Successful cases of ecosystem restoration. Ejido 16 de septiembre, Durango, Mexico. Source: CONAFOR (National Forestry Commission of Mexico) 
Also CONAZA, through the program for the conservation and sustainable use of soil and water, provides incentives for rural residents to contribute to the sustainable use and management of soil resources, water and vegetation. This program make investments in projects oriented to soil and water conservation, improvement and rational use of land cover. Financial support can be agreed either through arrangements with state governments or as direct execution with rural people. Among the major projects implemented by CONAZA to combat desertification include grassland establishment. This approach is a good idea to stop desertification just when the soil is un-vegetated. But, elimination of native vegetation such as shrubland to establish new plantations could not be the best alternative. Franklin et al. (2006) studied the extensive conversion from desert vegetation to grassland (Pennisetum ciliare), and they found that net primary productivity decreased because original vegetation was composed by trees and shrubs. They stated that replacement of vegetation will tend to loss biodiversity, which is more valuable in ecological terms, than milk or meat production.

Poor people living in arid and semiarid areas are more vulnerable to the effects of desertification. Other federal agencies such as the Ministry of Social Development are working to provide economic support for infrastructure development and social housing to communities with high and very high marginalization that make up the priority focus areas. These actions alleviate underlying causes of desertification related to social drivers. For example, this Ministry gave away 82,307 firewood-saving stoves in 125 municipalities in the whole Mexico for people who are living in extreme poverty. Each firewood-saving stove avoids releasing $2.7 \mathrm{CO}_{2}$ tonnes per year to the atmosphere, meaning 222,229 tonnes less to global atmospheric concentrations of $\mathrm{CO}_{2}$, as an alternative of mitigating climate change and its effects on environment (SEMARNAT \& INE, 2009).

Other documents of equal importance on environmental issues are the Mexico's National Communications to the United Nations Framework Convention on Climate Change (1st: $19972^{\text {nd: }} 2001,3^{\text {rd: }}$ 2006, 4th: 2009 and currently preparing the 5th: for the end of 2012) containing information for the Inventory of Greenhouse Gases updated for each period of analysis, as well as programs containing measures to mitigate and adapt to climate change (SEMARNAP, 1997; SEMARNAT \& INE, 2001, 2006, 2009). For the specific case of desertification, the $4^{\text {th }}$ National Communication of Mexico pinpoints the need to generate a national map updated on the vulnerability to desertification, which will serve as support for decision making. Likewise, each of the 32 Mexican states already have or are just working to develop their own programs of action to combat climate change through the state Ministries responsible for environment. These documents outline different alternatives and set up specific goals to achieve for mitigation and adaptation to climate change.

There are also non-governmental organizations widely involved in environmental issues. Such organizations serve as intermediaries between holders of forest resources and business sector who has the need to neutralize their emissions of greenhouse gases by investing in projects of environmental services such as carbon capture and other co-benefits. There are also individuals concerned on environment who are working to stop the line of degradation and desertification. A region of Oaxaca Mexico, characterized by semiarid climate, known as the Mixteca is proud to have a social organization that has successfully restored its ecosystem. This initiative is from a man named Jesús León Santos, who started to work in the early 1980's restoring the degraded lands in the Mixteca region. He is a leader of a 
democratic, farmer-led local environmental organization called the Center for Integral Small Farmer Development in the Mixteca (CEDICAM) who adopted several practices of sustainable agriculture and forest restoration in order to recover productivity in ecosystem. Nowadays, his organization involves 12 communities. They have planted more than one million trees and reforested more than 1000 ha. Main outcomes from these activities include $50 \%$ increase in agricultural production accompanied with soil and water conservation resulting in ecological, social and economic benefits. León was awarded the Goldman prize in 2008 honouring the titanic and prosperous effort to conserve and restore environmental capacities of semi-arid lands in Mexico. In addition, he has given various talks and visited environmental forums worldwide to share his experience as successful environmentalist.

Others believe that climate geoengineering could be an alternative to reverse the process of climate change. There are several alternatives for controlling climate and its effects on environment and societies, although much of these proposals are just in theory. In other words, these works just picture using environmental modelling to infer the effects of geoengineering alternatives in climate. For example, some visionary researchers have proposed changing leaf-albedo of crop plants through genetic manipulation to decrease global warming (Ridgwell et al., 2009). Other proposals include fertilization of the oceans with iron, because it was discovered that, large amounts of carbon can be fixed by phytoplankton (Keith et al., 2000, Güssow et al., 2010). Most of these alternatives of geoengineering have a great environmental risk, are very expensive and finally unaffordable. So, the most suitable approach to apply is the example of restoring forest ecosystems as described before. Semiarid ecosystems can be successfully restored and land degradation successfully reversed with appropriate practices directly on field.

\section{Conclusions}

Arid and semi-arid regions are characterized by short rainy seasons. When they experience dry periods, degradation of vegetation promotes erosion and thus desertification. Temperate regions with steep slopes are also vulnerable to loss of productive capacity because when vegetation that protects the soil is, naturally or induced, affected either storms or wind starts pouring the floor that lasted years to form complicating ecosystem restoration. At the same time, land use changes also have an impact on the climate; in fact, deforestation increases the evaporation of available water in the soil, minimizing transpiration by plants and reducing water storage. The increase of arid zones also has an impact on production and suspension of particles in the atmosphere and altering the climate mechanisms. Finally, the reduction of biomass and organic matter in degraded lands, reduces carbon storage in soil, contributing to global warming of the atmosphere, altering global atmospheric circulation and dramatically intensifying the frequency and impact of extreme events related to climate change.

Mexico, including government, non-governmental organizations and people, is actively fighting against degradation and desertification process in a variety of ways. Mexico's agenda related to the topic of environmental protection from the focus on mitigation of climate change is densely filled in all fields of action. These include environmental policy, financial issues and even direct action in the field to stop and reverse processes of degradation and desertification. Seeing the interactions of climate over ecosystems, and thus 
in people, was the only way, as the environmental issue becomes relevant in making decisions of governments and society, whose current major concerns are either mitigate or adapt to climate change effects. Mexico is playing correctly the key role of mitigating the effects of climate change. Perhaps the goal is still reachable, regaining the balance between society, ecosystem and climate.

\section{References}

Allen, C.; Macalady, A.; Chenchouni, H.; Bachelet, D.; McDowell, N.; Vennetier, M.; Kitzberger, T.; Rigling, A.; Breshears, D.; Hogg, E.; Gonzalez, P.; Fensham, R; Zhang, Z.; Castro, J.; Demidova, N.; Lim, J.; Allard, G.; Running, S.W.; Semerci, A. \& Cobb, N. (2010). A global overview of drought and heat-induced tree mortality reveals emerging climate change risks for forests. Forest Ecology and Management, Vol.259, No.4, (February 2010), pp. 660-684, ISSN 0378-1127

Amiraslani, F. \& Dragovich, D. (2011). Combating desertification in Iran over the last 50 years: an overview of changing approaches. Journal of Environmental Management, Vol.92, No.1, (September 2010), pp. 1-13, ISSN 0301-4797

Andréassian, V. (2004). Waters and forests: from historical controversy to scientific debate. Journal of Hydrology, Vol.291, No.1, (May 2004), pp. 1-27, ISSN 0022-1694

Arnalds, A. (2004). Carbon sequestration and the restoration of land health. Example of Iceland. Climatic Change, Vol.65, No.(3), (August 2004), pp. 333-346, ISSN 1573-1480

Barua, A.; Majumbder, M. \& Das, R. (2010). Estimating spatial variation of river discharge in face of desertification induced uncertainty, In: Impact of Climate Change on Natural Resource Management, B.K. Jana \& M. Majumder (Eds), 111-130, Springer, ISBN: 111130

Berg, E.; Henry, J.; Fastie, C.; De Volder, A. \& Matsuoka, S. (2006). Spruce beetle outbreaks on the Kenai Peninsula, Alaska, and Kluane National Park and Reserve, Yukon Territory: relationship to summer temperatures and regional differences in disturbance regimes. Forest Ecology and Management, Vol.227, No. 3, (June 2006), pp. 219-232, ISSN 0378-1127

Beskow, S.; Mello, C.; Norton, L.; Curi, N.; Viola, M. \& Avanzi, J. (2009). Soil erosion prediction in the Grande River Basin, Brazil using distributed modeling. Catena Vol.79, No.1, (October 2009), pp. 49-59, ISSN 0341-8162

Bied-Charreton, M. (2008). Integrating the combat against desertification and land degradation into negotiations on climate change: a winning strategy, French Scientific Committee on Desertification, (November 2008)

Breshears, D.; Cobb, N.; Rich, P.; Price, K.; Allen, C.; Balice, R.; Romme, W.; Kastens, J.; Floyd, M.; Belnap, J.; Anderson, J.; Myers, O. \& Meyer, C. (2005). Regional vegetation die-off in response to global-change-type drought. Proceedings of the National Academy of Sciences of the United States of America, Vol.102, No.42, (October 2005), pp. 15144-15148, ISSN 0027-8424

Burroughs, W. (2007). Climate change. A Multidisciplinary approach. 2d Ed. Cambridge University Press, ISBN 978-0-521-69033-1.

Clinton, B.; Boring, L. \& Swank, W. (1993). Canopy gap characteristics and drought influences in oak forests of the Coweeta Basin. Ecology, Vol.74, No.5, (July 1993), pp. 1551-1558, ISSN 0012-9658 
Cochard, H. (2006). Cavitation in trees. Comptes Rendus Physique, Vol.7, No.9, (NovemberDecember 2006), pp. 1018-1026, ISSN 1631-0705

CONAZA. (1994). Plan de acción para combatir la desertificación en México. Comisión Nacional de Zonas Áridas. Secretaría de Desarrollo Social. Saltillo, Coah. 160 p.

Davoudi, S.; Crawford, J. \& Mehmood, A. (2009). Planning for climate change. Strategies for mitigation and adaptation for spatial planners. Earthscan, ISBN 978-1-84407-662-8

DOF (Diario Oficial de la Federación). (2011). Reglamento de la Ley de Desarrollo Rural Sustentable. Ultima modificación publicada en el Diario Oficial de la Federación el 26 de mayo de 2011. Mexico, D.F.

Etchevers, J.; Prat, C.; Balbontin, C.; Bravo, M. \& Martínez, M. (2009). Influence of land use on carbon sequestration and erosion in México: a review, In: Sustainable Agriculture, E. Lichtfouse, M. Navarrete, P. Debaeke, V. Souchere \& C. Alberola (Eds.), 87-96, Springer, ISBN 978-90-481-2665-1

Franklin, K.; Lyons, K.; Nagler, P.; Lampkin, D.; Glenn, E.; Molina, F.; Markow, T. \& Huete, A. (2006). Buffelgrass (Pennisetum ciliare) land conversion and productivity in the plains of Sonora, Mexico. Biological Conservation, Vol.127, No.1, (January 2006), pp: 62-71, ISSN 0006-3207

Fujimaki, H.; Shiozawa, S. \& Inoue, M. (2003). Effect of salty crust on soil albedo. Agricultural and Forest Meteorology, Vol. 118. No.1-2, (August 2003), pp. 125-135, ISSN: 0168-1923

Geist, H. \& Lambin, E. (2004). Dynamic causal patterns of desertification. Bioscience, Vol.54, No.9, (September 2004), pp. 817-829, ISSN 0006-3568

Goudie, A. (2008). The history and nature of wind erosion in deserts. Annual Review of Earth and Planetary Sciences, Vol.36, (May 2008), pp. 97-119, ISSN 0084-6597

Grainger, A.; Stafford, M.; Squires, V. \& Glenn, E. (2000). Desertification and climate change: the case for greater convergence. Mitigation and Adaptation Strategies for Global Change, Vol.5, No.4, (December 2000), pp. 361-377, ISSN 1381-2386

Günter, H.; Oswald, Ú.; Grin, J. \& Czeslaw, M. (2009). Facing global environmental change. Environmental, human, energy, food, health and water security concepts, Springer, ISBN 978-3-540-68487-9

Güssow, K.; Proelss, A.; Oschlies, A.; Rehdanz, K \& Rickels, W. (2010). Ocean iron fertilization: why further research is needed. Marine Policy, Vol.34, No.5, (September 2010), pp.911-918, ISSN 0308-597X

Hardy, J. (2003). Climate change. Causes, Effects and Solutions. John Wiley \& Sons Ltd. ISBN 0470-85018-3

Henson, R.H. (2008). The rough guide to Climate Change. The symptomps. The science. The Solutions. Rough Guides Ltd, ISBN 9-781-85828-105-5

Hogg, E.; Brandt, J.; \& Michaellian, M. 2008. Impacts of a regional drought on the productivity, dieback, and biomass of western Canadian aspen forests. Canadian Journal of Forest Research, Vol.38, No.6, (April 2008), pp. 1373-1384.

Juárez, A. \& Rodríguez, D. (2003). Efecto de los incendios forestales en la regeneración de Pinus oocarpa. var. ochoterenae. Revista Chapingo. Serie Ciencias Forestales y del Ambiente, Vol.9, No.2, (Diciembre 2003), pp. 125-130, ISSN 0186-3231

Keith, D. (2000). Geoengineering the Climate. History and Prospect. Annual Review of Environment and Resources, Vol.25, (November 2000), pp. 245-284, ISSN 1543-5938 
Kemp, P.; Reynolds, J.; Virginia, R.A. \& Withford, W. (2003). Decomposition of leaf and root litter of Chihuahuan desert shrubs: effects of three years of summer drought. Journal of Arid Environments, Vol.53, No.1, (January 2003), pp. 21-39, ISSN 0140-1963

Kurz, W.; Dymond, C.; Stinson, G.; Rampley, G.; Neilson, E.; Carroll, A.; Ebata, T; \& Safranyik, L. (2008). Mountain pine beetle and forest carbon feedback to climate change. Nature. Vol.452, (January 2008), pp. 987-990, ISSN 0028-0836

Kusky, T. (2009). The hazardous Earth. Climate Change. Shifting Glaciers, Deserts and Climate Belts. Facts on File, Inc. Infobase Publishing. ISBN 978-0-8160-6466-3

Lal, P.; Alavalapati, J. \& Mercer, E. (2011). Socio-economic impacts of climate change on rural United States. Mitigation and Adaptation Strategies for Global Change, Vol.7, No.7, (October 2011), pp. 819-844, ISSN 1381-2386

Latta, G.; Temesgen, H.; Adams, D. \& Barrett, T. (2010). Analysis of potential impacts of climate change on forests of the United States Pacific Northwest. Forest Ecology and Management, Vol.259, No.4, (February 2010), pp. 720-729, ISSN 0378-1127

Letcher, T. (2009). Climate Change: observed impacts on planet Earth. Elsevier. ISBN 978-0-44453301-2

Lu, H. \& Shao, Y. (2001). Toward quantitative prediction of dust storms: an integrated wind erosion modelling system and its applications. Environmental Modelling and Software, Vol.16, No.3, (April 2001), pp. 233-249, ISSN 1364-8152

Maherali, H.; Pockman, W. \& Jackson, R. (2004). Adaptive variation in the vulnerability of woody plants to xylem cavitation, Ecology, Vol.85, No.8, (August 2004), pp. 21842199, ISSN 0012-9658

Manzano, M. \& Návar, J. (2000). Processes of desertification by goats overgrazing in the Tamaulipan thornscrub (matorral) in north-eastern Mexico. Journal of Arid Environments, Vol.44, No.1, (January 2000), pp. 1-17, ISSN 0140-1963

Millennium Ecosystem Assessment. (2005). Ecosystems and human well-being: Desertification Synthesis. World Resources Institute, Washington, D.C., USA. ISBN 1-56973-590-5

Nagaz, K.; Moncef, M. \& Ben-Mechlia, N. (2011). Impacts of irrigation regimes with saline water on carrot productivity and soil salinity. Journal of the Saudi Society of Agricultural Sciences, In press, (Available online 15 June 2011), ISSN 1658-077X

Navarrete, J.; Ramírez, M. \& Pérez D. (2011). Logging within protected areas: spatial evaluation of the monarch butterfly biosphere reserve, Mexico. Forest Ecology and Management, Vol.262, No.4, (August 2011), pp. 646-654, ISSN 0378-1127

Oldfield, F. (2005). Environmental Change. Key issues and alternative approaches. Cambridge University Press. ISSN 978-0-521-53633-2

Pando, M.; Gutierrez, M.; Maldonado, A.; \& Jurado, E. (2002). Evaluación de los procesos de desertificación en una cuenca hidrológica del NE de México. Ciencia UANL, Vol.5, No.4, (Octubre-Diciembre 2002), pp. 519-524, ISSN 2007-1175

Perry, R. (1986). Desertification processes and impacts in irrigated regions. Climatic Change, Vol.9, No.1, (August 1986), pp. 43-47, ISSN 1573-1480

Podhrázscká, J. \& Novotný, I. (2007). Evaluation of the wind erosion risks using GIS. Soil and Water Research, Vol.2, No.1, pp. 10-14, ISSN 1801-5395

Rafferty, J. (2011). The living Earth. Climate and Climate Change. Britannica Educational Publishing, ISBN 978-1-61530-388-5 
Rappaport, A. \& Hammond, S. (2007). Degress that matter. Climate change. The MIT Press. ISBN 978-0-262-18258-4

Rasmussen, K.; Fog, B. \& Madsen, J. (2001). Desertification in reverse? Observations from northern Burkina Faso. Global Environmental Change, Vol.11, No.4, (December 2001) pp. 271-282, ISSN 0959-3780

Ridgwell, A.; Sigarayer, J.; Hetherington, A. \& Valdes, P. 2009. Tackling regional climate change by leaf-albedo bioengineering. Current Biology, Vol. 19, No.2, (January 2009), pp. 146-150, ISSN 0960-9822

Runnström, M. (2000). Is northern China winning the battle against desertification?. Ambio, Vol.29, No.8, (April 2000), pp. 468-476, ISSN 0044-7447

Santini, M.; Caccamo, G.; Laurentu, A.; Noce, S. \& Valentini, R. (2010). A Multi-component GIS framework for desertification risk assessment by an integrated index. Applied Geography, Vol.30, No.3, (July 2010), pp. 394-415, ISSN 0143-6228

Savage, M. (1997). The role of anthropogenic influences in a mixed-conifer forest mortality episode. Journal of Vegetation Science, Vol.8, No.1, (February 1997), pp. 95-104, ISSN 1100-9233

SEMARNAP. (1997). México, 1ra Comunicación Nacional ante la Convención Marco de las Naciones Unidas sobre el Cambio Climático. Secretaría del Medio Ambiente, Recursos Naturales y Pesca. México, D.F. 149 p.

SEMARNAT. (2009). Consecuencias sociales del cambio climático en México. Análisis y propuestas. Secretaría del Medio Ambiente y Recursos Naturales. ISBN 978-968-817-933-8

SEMARNAT \& COLPOS. (2003). Evaluación de la degradación del suelo inducida por el hombre, escala 1:250000. México, Secretaría del Medio Ambiente y Recursos Naturales, Colegio de Postgraduados

SEMARNAT \& INE. (2001). México, 2da Comunicación Nacional ante la Convención Marco de las Naciones Unidas sobre el Cambio Climático. Secretaría del Medio Ambiente y Recursos Naturales, Instituto Nacional de Ecología, ISBN 9968-817-494-7

SEMARNAT \& INE. (2006). México, 3ra Comunicación Nacional ante la Convención Marco de las Naciones Unidas sobre el Cambio Climático. Secretaría del Medio Ambiente y Recursos Naturales, Instituto Nacional de Ecología, ISBN 968-817-811-X

SEMARNAT \& INE. (2009). México, 4ta Comunicación Nacional ante la Convención Marco de las Naciones Unidas sobre el Cambio Climático. Secretaría del Medio Ambiente y Recursos Naturales, Instituto Nacional de Ecología, ISBN 978-607-7908-00-5

Shao, Y. \& Dong, C. (2006). A review on East Asian dust storm climate, modelling and monitoring. Global and Planeraty Change, Vol.52, No.1, (July 2006), pp. 1-22, ISSN 0921-8181

SINADES. (2009). Estrategia Nacional de Manejo Sustentable de Tierras. Sistema Nacional de Lucha contra la Desertificación y la Degradación de los Recursos Naturales (SINADES). Secretaría del Medio Ambiente y Recursos Naturales. Dirección General del Sector Primario y Recursos Naturales Renovables, Mexico, ISBN 978-607-7908-42-5

Sivakumar, M. (2007). Interactions between climate and desertification. Agricultural and Forest Meteorology, Vol.142, No.2, (February 2007), pp. 143-155, ISSN: 0168-1923

UNCCD. (2004). Preserving our common ground. UNCCD 10 years on. United Nations Convention to Combat Desertification. Bonn, Germany. 20 p.

Ustin, S.; Palacios-Orueta, P.; Whiting, M.; Jacquemoud, S. \& Li, L. (2009). Remote sensing based assessment of biophysical indicators for land degradation and 
desertification. In: Recent Advances in Remote Sensing and Geoinformation Processing for Land Degradation Assessment, A. Röder \& J. Hill (Eds), CRC Press/Balkema/Taylor \& Francis Group, pp. 15-44, ISBN 978-0-415-39769-8

Viglizzo, E. \& Frank, F. (2006). Ecological interactions, feedbacks, thresholds and collapses in the Argentine Pampas in response to climate and farming during the last century. Quaternary International, Vol.158, No.1, (December 2006), pp. 122-126, ISSN 1040-6182

Voelker, S.; Muzika, R. \& Guyette, R. (2008). Individual tree and stand level influences on the growth, vigor, and decline of Red Oaks in the Ozarks. Forest Science, Vol.54, No.1, (February 2008), pp. 8-20, ISSN 0015-749X

Zhou, P.; Luukkanen, O.; Tokola, T. \& Nieminen, J. (2008). Effect of vegetation cover on soil erosion in a mountainous watershed. Catena, Vol.75, No.3, (November 2008), pp. 319-325, ISSN 0341-8162 


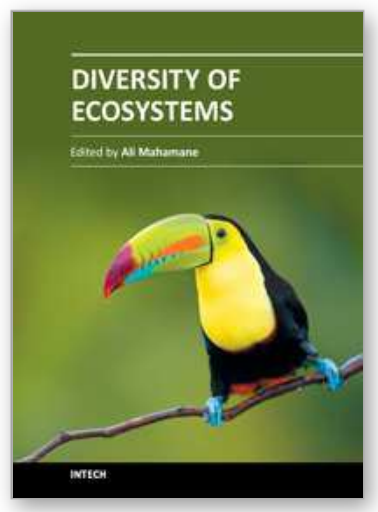

\author{
Diversity of Ecosystems \\ Edited by Prof. Mahamane Ali
}

ISBN 978-953-51-0572-5

Hard cover, 484 pages

Publisher InTech

Published online 27, April, 2012

Published in print edition April, 2012

The ecosystems present a great diversity worldwide and use various functionalities according to ecologic regions. In this new context of variability and climatic changes, these ecosystems undergo notable modifications amplified by domestic uses of which it was subjected to. Indeed the ecosystems render diverse services to humanity from their composition and structure but the tolerable levels are unknown. The preservation of these ecosystemic services needs a clear understanding of their complexity. The role of research is not only to characterise the ecosystems but also to clearly define the tolerable usage levels. Their characterisation proves to be important not only for the local populations that use it but also for the conservation of biodiversity. Hence, the measurement, management and protection of ecosystems need innovative and diverse methods. For all these reasons, the aim of this book is to bring out a general view on the function of ecosystems, modelling, sampling strategies, invading species, the response of organisms to modifications, the carbon dynamics, the mathematical models and theories that can be applied in diverse conditions.

\title{
How to reference
}

In order to correctly reference this scholarly work, feel free to copy and paste the following:

Carlos Arturo Aguirre-Salado, Eduardo Javier Treviño-Garza, Oscar Alberto Aguirre-Calderón, Javier JiménezPérez, Marco Aurelio González-Tagle and José René Valdez-Lazalde (2012). Desertification-Climate Change Interactions - Mexico's Battle Against Desertification, Diversity of Ecosystems, Prof. Mahamane Ali (Ed.), ISBN: 978-953-51-0572-5, InTech, Available from: http://www.intechopen.com/books/diversity-ofecosystems/desertification-climate-change-interactions-mexico-s-battle-against-desertification

\section{INTECH}

open science | open minds

\section{InTech Europe}

University Campus STeP Ri

Slavka Krautzeka 83/A

51000 Rijeka, Croatia

Phone: +385 (51) 770447

Fax: +385 (51) 686166

www.intechopen.com

\section{InTech China}

Unit 405, Office Block, Hotel Equatorial Shanghai

No.65, Yan An Road (West), Shanghai, 200040, China 中国上海市延安西路65号上海国际贵都大饭店办公楼 405 单元

Phone: +86-21-62489820

Fax: +86-21-62489821 
(C) 2012 The Author(s). Licensee IntechOpen. This is an open access article distributed under the terms of the Creative Commons Attribution 3.0 License, which permits unrestricted use, distribution, and reproduction in any medium, provided the original work is properly cited. 